
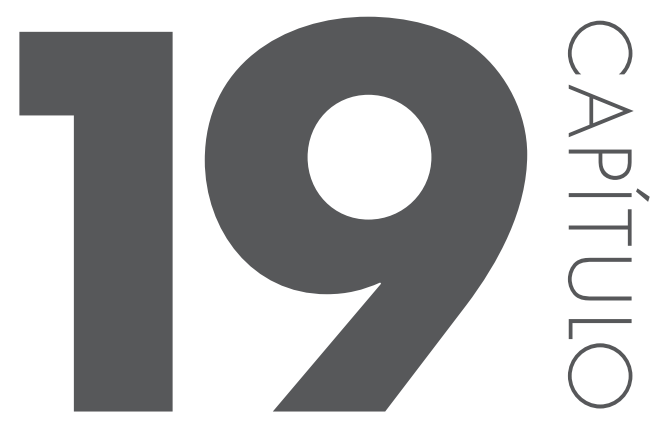

\title{
PEQUENOS RNAS E APLICACOÕES DE RNAi EM PLANTAS
}

Franceli R. Kulcheski

Rogério Margis

\subsection{INTRODUC̣ÃO}

Nas últimas décadas, um dos eventos mais marcantes na área das ciências biológicas foi a identificação e caracterização do papel dos pequenos ácidos ribonucleicos (do inglês small RNAs - sRNAs) não codificantes na regulação da expressão gênica. Essa descoberta modificou significativamente o entendimento dos mecanismos de regulação dos genes, bem como o controle de diversos processos biológicos em eucariotos.

Por muito tempo acreditou-se que o RNA não passava de uma molécula intermediária entre ácido desoxirribonucleico (DNA) e proteínas, e que de forma alguma poderia exercer uma ampla regulação da expressão de genes, principalmente considerando pequenos fragmentos de RNA, os quais se acreditava serem apenas resíduos da degradação de longos RNAs mensageiros (mRNAs).

A descoberta do silenciamento gênico promovido por pequenas moléculas de RNA foi evidenciada em plantas nos anos $1990^{1}$; entretanto, a compreensão do mecanismo de ação desses pequenos RNAs só ocorreu alguns anos depois, por meio de estudos com o nematódeo Caenorhabditis elegans ${ }^{2}$. Duas décadas transcorreram até os dias atuais, período marcado por um significativo avanço nas tecnologias de sequenciamento de ácidos nucleicos (bigh throughput 
sequencing ou deep sequencing), que impulsionou a identificação e caracterização de várias classes desses pequenos $\mathrm{RNAs}^{3}$, dentre as quais: pequenos RNAs provenientes de vírus (virus-derived short interfering RNAs - vsiRNAs), pequenos RNAs naturais antissenso (natural antisense short interfering RNAs - nat-siRNAs), pequenos RNAs heterocromáticos (beterochromatic small interfering RNAs - hc-siRNA), microRNAs (miRNAs), pequenos RNAs atuantes em trans (trans-acting siRNA - tasi-RNAs) e pequenos RNAs provenientes de fragmentos de tRNAs ( $t R N A$-derived RNA fragments - tRFs).

Todos esses sRNAs agem como reguladores da transcrição gênica, podendo atuar pré, pós ou transcricionalmente. Entretanto o controle pós-transcricional é o processo biotecnológico mais amplamente utilizado para obter-se o silenciamento gênico com o uso destas moléculas. De forma geral, esses sRNAs agem sobre um mRNA. As diferentes classes de sRNAs distinguem-se pela sua origem, pela natureza dos seus genes-alvos e pela conservação evolucionária. Por exemplo, as duas principais classes de sRNAs, os pequenos RNAs de interferência (do inglês small interfering RNAs - siRNAs) e os miRNAs podem ser diferenciados pelo tipo de alvo sobre os quais atuam. Os siRNAs têm como alvo mRNAs derivados de transgenes, vírus, elementos transponíveis e/ou genes endógenos, enquanto os miRNAs têm como alvo mRNAs endógenos codificadores de proteínas, que geralmente pertencem a uma mesma família gênica.

O silenciamento por RNA tem sido usado como uma importante ferramenta pela genômica funcional, e tem sido também aplicado ao melhoramento genético de plantas através de duas formas. A primeira é o silenciamento de genes que afetam um incremento das características agronômicas ou que afetam o desempenho da planta durante situações de estresses. A outra forma é silenciando genes-alvos que não são endógenos das plantas, mas, sim, de outros organismos que afetam seu desenvolvimento, subsistência e produção. Nesse caso, o foco seriam os agentes causais de estresses bióticos, como insetos-praga, nematódeos, viroses e plantas daninhas.

Assim, procuramos apresentar o atual cenário dos sRNAs, bem como formas de estudá-los e as atuais e futuras aplicações do mecanismo de interferência por RNA (RNAi) em plantas. Um breve histórico sobre a descoberta de pequenos RNAs e sobre o mecanismo de silenciamento de RNA é seguido da descrição das principais classes de pequenos RNAs detectados em plantas, bem como a metodologia de análise de expressão desses RNAs via transcrição reversa seguida da reação em cadeia da DNA polimerase quantitativa (RT-qPCR). Por último, abordam-se as possíveis aplicações biotecnológicas de sRNAs no estudo da função gênica e no melhoramento de plantas. 


\subsection{HISTÓRICO}

A descoberta do mecanismo de interferência por RNA (RNAi) foi precedida pela descoberta de pequenos RNAs antissenso expressos em plantas transgênicas ${ }^{4}$. Em 1990, Napoli e colaboradores ${ }^{1}$ tentaram alterar a cor de flores de petúnia através da introdução de cópias adicionais do gene codificador da enzima chalcona sintase, uma enzima-chave para a coloração rosa ou violeta das flores de petúnia. O objetivo da superexpressão desse gene era a obtenção de flores mais escuras. Entretanto, o fenótipo observado foi o de flores menos pigmentadas, ou até mesmo completamente ou parcialmente brancas, indicando que a atividade da chalcona sintase havia sido substancialmente diminuída. De fato, ambos os genes endógenos ou transgenes apresentavam-se reprimidos nas flores brancas ${ }^{1}$. Investigações posteriores desse fenômeno em plantas indicaram que a repressão deveu-se à inibição pós-transcricional da expressão gênica em razão de um aumento da taxa de degradação do mRNA ${ }^{5}$. Esse fenômeno foi então chamado de cossupressão da expressão do gene, mas o mecanismo molecular permanecia desconhecido até aquele momento.

Algum tempo após o trabalho realizado em petúnias, virologistas que pesquisavam o melhoramento de plantas quanto à resistência a doenças virais observaram um fenômeno similar ao descrito em petúnias transgênicas. Já se sabia que plantas que expressavam proteínas específicas do vírus demonstravam tolerância aumentada e até resistência à infecção viral. Entretanto, não se esperava que plantas carregando apenas sequências curtas de RNA viral não codificante também pudessem apresentar níveis similares de proteção. Alguns pesquisadores acreditavam que esse fato devia-se à capacidade do RNA viral (produzido pelos transgenes) de inibir a replicação viral ${ }^{6}$. $O$ experimento reverso, no qual sequências curtas de genes de planta foram introduzidos em vírus, mostrou que o gene-alvo foi suprimido em plantas infectadas. Esse fenômeno recebeu o nome de silenciamento gênico induzido por vírus, ou, em inglês, virus-induced gene silencing (VIGS), e o conjunto desse tipo de fenômeno foi coletivamente chamado de silenciamento gênico pós-transcricional, ou post-transcriptional gene silencing (PTGS) ${ }^{7}$. Após essas observações iniciais em plantas, vários laboratórios em todo o mundo iniciaram uma busca por tal fenômeno em outros organismos ${ }^{8,9}$.

Em 1998, Craig Mello e Andrew Fire publicaram na revista Nature um trabalho reportando um potente efeito de silenciamento gênico após injetar um RNA de fita dupla no nematódeo Caenorhabditis elegans ${ }^{2}$. Investigando a produção de proteínas musculares, eles observaram que as injeções de 
mRNA ou RNA antissenso não afetavam a produção de determinada proteína, mas quando era injetado um RNA de fita dupla, o silenciamento das proteínas-alvo acontecia com sucesso. Ao final desse trabalho, eles estabeleceram o termo "interferência por RNA", ou, em inglês, RNA interference (RNAi). A descoberta de Fire e Mello foi particularmente notável, pois foi o primeiro trabalho a identificar o agente causal do fenômeno que resultava em silenciamento de genes, o que lhes rendeu o prêmio Nobel em fisiologia ou medicina do ano de 2006.

\subsection{PEQUENOS RNAS}

Nesta seção estão descritas as principais classes de pequenos RNAs detectados em plantas até o momento.

\subsection{1 siRNAs}

Pequenos RNAs de interferência (siRNAs) foram primeiramente descobertos em plantas, e podem ser originados tanto de componentes endógenos do transcriptoma quanto a partir de respostas a infecções virais exógenas ou de RNA dupla fita (double-stranded RNAs - dsRNAs) introduzidos via transgenia. Esses componentes endógenos ou exógenos podem tanto consistir em um precursor fita dupla formado a partir de uma hibridização intermolecular de duas fitas complementares de RNA quanto a partir de uma única fita de RNA que possui uma autocomplementariedade intramolecular, a qual originará uma estrutura em forma de grampo, ou hairpin (Figura 19.1). Os siRNAs participam de inúmeros processos, tais como: defesa contra vírus, silenciamento de transposons e transgenes, estabelecimento da heterocromatina e silenciamento pós-transcricional ${ }^{10}$.

Pequenos RNAs exógenos podem ser originados a partir da interação de plantas com vírus e a partir de transgenes inseridos em plantas. Em plantas, existem diferentes mecanismos de geração de siRNAs via PTGS: silenciamento de transgenes (S-PTGS), silenciamento induzido por vírus (VIGS) e (silenciamento induzido por sequências invertidas (IR-PTGS).

Os dsRNAs oriundos de vírus e de transgenes são reconhecidos pela maquinaria de silenciamento da planta hospedeira ${ }^{11}$. Dependendo da via de geração dos siRNAs, diferentes enzimas participarão do processo. Por exemplo, enzimas DICER-LIKE 3 (DCL3) processam siRNAs de 24 nucleotídeos 


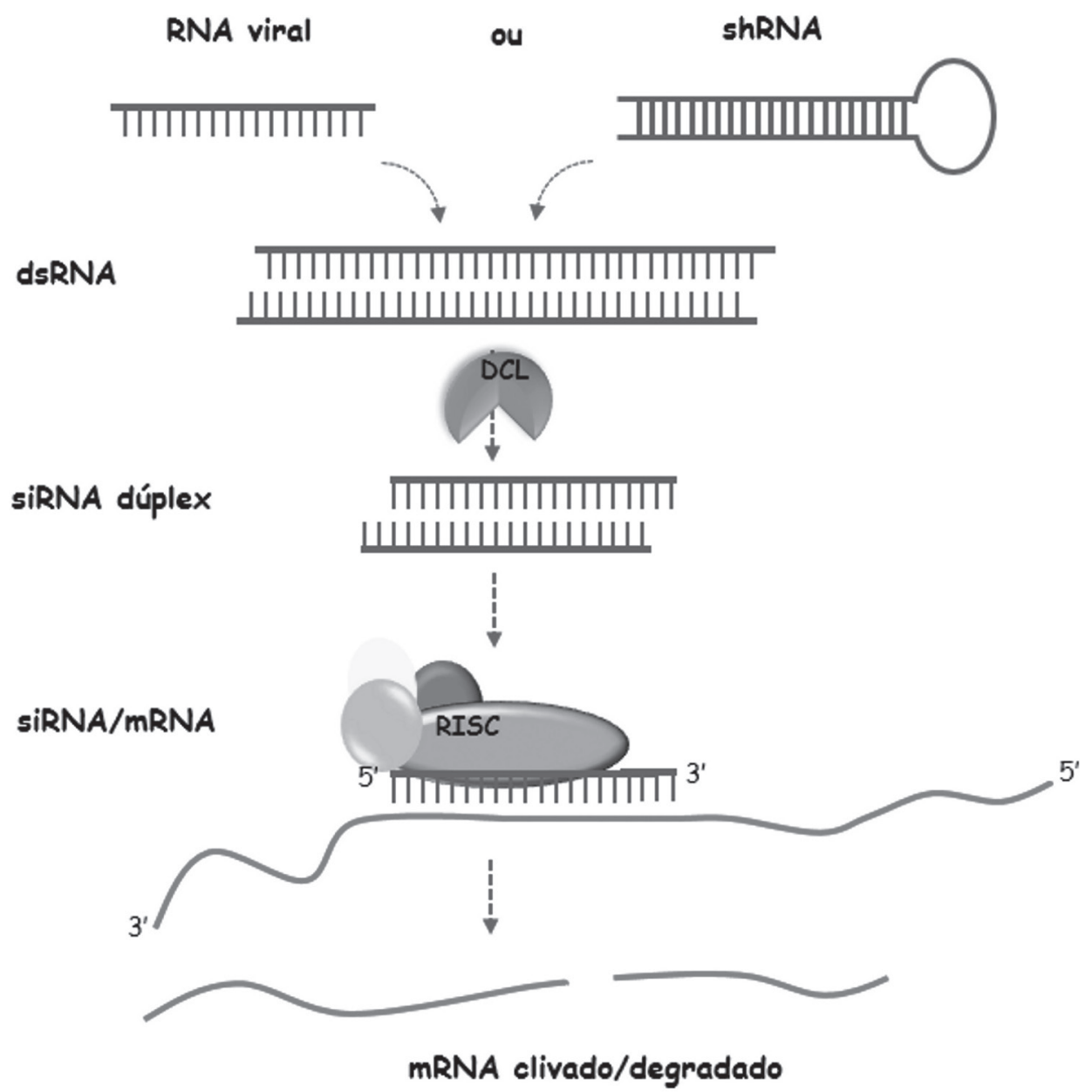

Figura 19.1 Representação esquemática da formação de siRNAs em plantas. RNAs de dupla fita (dsRNA) originados de diversas fontes, tais como: RNAs replicativos produzidos durante uma infecção viral ou transcritos artificiais expressos em organismos transgênicos que tenham a capacidade de produzir estruturas em forma de grampo (ou hairpin - shRNA) serão processados por enzimas DICER-LIKE (DCL) gerando siRNA dúplex. Após a separação do dúplex de siRNA, uma das fitas será transferida e acoplada ao complexo de silenciamento induzido por RNA (RNA-induced silencing complex - RISC), no qual promoverá reconhecimento, clivagem e degradação de um mRNA-alvo.

(nt), enquanto enzimas DCL4 produzem siRNAs de 21 nt. Esses siRNAs gerados a partir do processamento de dsRNAs de origem viral são denominados vsiRNAs, estando geralmente relacionados ao silenciamento viral ${ }^{11}$. Em contrapartida, como parte da coevolução, os vírus possuem proteínas de inibição do mecanismo de silenciamento disparado pelo organismo 
hospedeiro. Portanto, esses exo-siRNAs estão relacionados à defesa antiviral, pois os siRNAs produzidos levam ao silenciamento do vírus. Além disso, o silenciamento de transgenes ocorre pela geração de siRNAs a partir dos dsRNAs transcritos dos transgenes inseridos de forma estável e/ou transiente no genoma hospedeiro.

$\mathrm{Na}$ via de produção de siRNAs endógenos, podem ser destacados dois grupos: os siRNA heterocromáticos (hc-siRNAs) e os transcritos de siRNA natural antissenso (nat-siRNAs). Outras subdivisões podem ser encontradas em outros trabalhos; entretanto, neste capítulo escolhemos abordar as classes mais amplamente detectadas.

Os hc-siRNAs são transcritos a partir de regiões repetitivas do genoma (tais como transposons, retroelementos e DNA ribossomal) por uma RNA polimerase IV (ou ainda por uma RNA pol V). Esses transcritos são processados em fragmentos de $24 \mathrm{nt}$ originados pela atividade de uma DCL $3^{12-14}$. Os hc-siRNAs são responsáveis pelo silenciamento transcricional por uma via conhecida como metilação do DNA dependente de RNA (RNA-dependent DNA methylation - RdDM) ${ }^{15}$.

Os hc-siRNAs promovem a metilação do DNA de regiões homólogas à sua sequência em um processo que requer a ação de uma enzima Argonauta (AGO4) e da RNA pol V presentes em um mesmo complexo proteico ${ }^{16}$. O complexo de silenciamento induzido por RNA (ou RNA-induced silencing complex - RISC) contendo hc-siRNA, AGO4 e RNA pol V recruta uma metiltransferase (domains rearranged methyltransferase 2 - DRM2) e uma metiltransferase defectiva em metilação de DNA direcionada por RNA (defective in RNA-directed DNA methylation - DRD1), as quais promovem a metilação do DNA e das histonas, proporcionando, assim, um silenciamento transcricional lócus-específico ${ }^{16}$. Foi demonstrado que AGO6 também pode estar envolvida na rota dos hc-siRNAs, possuindo características análogas às de $\mathrm{AGO} 4^{17}$.

Outro grupo de siRNAs são os pequenos RNAs naturais antissenso (nat-siRNAs), os quais são originados de dsRNAs formados por homologia entre dois transcritos que podem ser RNAs não codificantes (non conding RNAs - ncRNAs) ou mRNAs ${ }^{18}$. Esses transcritos antissenso naturais podem ser originados do mesmo lócus quando este é transcrito em ambos os sentidos (cis-NAT) ou de lócus diferentes (trans-NAT) ${ }^{18}$. Até o momento, observou-se na maioria dos trabalhos que um dos NATs é transcrito constitutivamente, e a indução do outro NAT é que promove a formação do dsRNA precursor. Foi observado que em Arabidopsis thaliana essa indução ocorre sob estresse salino ou infecção bacteriana ${ }^{19,20}$. 
O transcrito induzido por estresse é sintetizado por uma RNA pol IV e não codifica proteínas ${ }^{19}$. A região complementar aos dois transcritos é então reconhecida pela DCL2, a qual cliva o dsRNA formando os nat-siRNAs primários que consistem em sequências de 24 nt metilados por uma enzima Hua Enhancer 1 (HEN1) ${ }^{19}$. Os nat-siRNAs são acoplados ao complexo RISC, onde ocorrerá a clivagem dos mRNAs-alvos ${ }^{21}$. $\mathrm{O}$ alvo do nat-siRNA primário é o próprio transcrito NAT, o qual é expresso constitutivamente. Após a clivagem de NAT, uma RNA dependente de RNA polimerase (RNA-dependent RNA polymerase - RDR6) produz dsRNAs que são reconhecidos por DCL1, que, por sua vez, produz os nat-siRNAs secundários de $21 \mathrm{nt}$, os quais também terão como alvo os próprios NATs constitutivos ${ }^{19,20}$.

\subsubsection{MicroRNAs}

Os microRNAs (miRNAs) podem ser considerados como a principal classe de pequenos RNAs reguladores envolvidos na regulação da expressão gênica, atuando em uma série de processos biológicos, como crescimento, desenvolvimento e adaptação a diversos estresses. O primeiro miRNA descrito, lineage-deficient-4 (lin-4), foi descoberto em 1993 e identificado como regulador pós-transcricional do gene lin-14, que está envolvido no controle do desenvolvimento larval de C. elegans ${ }^{22}$. Em plantas, a identificação de miRNAs e da enzima envolvida em sua biogênese ocorreu em Arabidopsis pela primeira vez, em 2002, por dois grupos distintos ${ }^{23,24}$. Atualmente, miRNAs têm sido identificados em inúmeras espécies, e todas as sequências de seus precursores e formas maduras estão disponíveis em um banco de dados público denominado miRBase"25-29. O aumento na identificação de miRNAs tem demonstrado a relação destes com diversas processos celulares. Inúmeros miRNAs identificados em plantas foram associados com o desenvolvimento $^{30-32}$, sinalização hormonal ${ }^{33}$, floração e determinação sexual ${ }^{34}$, bem como com respostas a estresses bióticos e abióticos ${ }^{30,35-39}$.

Análises experimentais e computacionais têm demonstrado que muitos miRNAs, bem como seus alvos, são conservados entre espécies de monocotiledôneas (arroz) e dicotiledôneas (Arabidopsis) ${ }^{40-42}$. Esses estudos têm evidenciado que a origem dos miRNAs ocorreu em uma fase inicial da evolução dos eucariotos, antecedendo à divergência entre plantas monocotiledôneas e dicotiledôneas.

* Ver http://www.mirbase.org. 
Em plantas, os genes de miRNAs são transcritos por uma RNA polimerase do tipo II (RNA pol II) ${ }^{43,44}$; embora alguns miRNAs possam também ser transcritos pela RNA pol $\mathrm{III}^{45}$. Os transcritos iniciais de miRNAs são chamados miRNAs primários (pri-miRNAs). A RNA pol II gera pri-miRNAs capeados e poliadenilados tanto em plantas quanto em animais $^{44}$. Após a transcrição dos pri-miRNAs, a proteína DAWDLE (DDL) liga-se a eles, protegendo-os da degradação. Este pri-miRNA forma uma estrutura em formato de grampo (hairpin structure) imperfeita, a qual será processada em um precursor do miRNA (pré-miRNA) também conhecido como estrutura stem-loop. Em plantas, tanto pri quanto pré-miRNAs são processados no núcleo por uma enzima do tipo RNase III denominada $\operatorname{DCL}^{46}$. O processamento do pri-miRNA em pré-miRNA ocorre em um centro de processamento nuclear conhecido como corpo-D (do inglês $D$-body, ou SmD3/SmB-body). Embora não esteja clara a questão do comprimento dos pri-miRNAs, sabe-se que todos podem dobrar e originar uma estrutura secundária em formato de grampo ${ }^{47}$. Possuir estruturas hairpin é uma importante característica de miRNAs ${ }^{48}$. Pré-miRNAs, ainda no núcleo, são clivados pela DCL1 e pela proteína HYPONASTIC LEAVES 1 (HYL1), originando um dúplex miRNA:miRNA*46,49,50. Os dúplex miRNA:miRNA* recentemente processados possuem dois nucleotídeos sobressalentes na região terminal 3' de cada fita e são facilmente degradados por uma classe de exonucleases conhecidas como small RNA degradading nuclease (SDN) ${ }^{51}$. Para estabilizar o dúplex miRNA:miRNA*, uma metiltransferase de pequenos RNAS, HEN1, imediatamente metila os nucleotídeos no terminal 3' de cada fita, prevenindo, assim, sua uridilação e subsequente degradação ${ }^{52}$. Em mutantes hen1, observou-se falta ou acúmulo mínimo de miRNAs, sugerindo o papel de HEN1 na proteção de miRNAs contra a degradação ${ }^{53}$. O dúplex miRNA/miRNA* é então transportado do núcleo para o citoplasma pela proteína de membrana HASTY ${ }^{54}$ (Figura 19.2).

No citoplasma, o dúplex miRNA:miRNA* é separado e a fita de miRNA é incorporada ao complexo RISC, formando, assim, o complexo miR-RISC ${ }^{55}$, no qual uma proteína AGO1 cliva o mRNA-alvo no meio do dúplex mRNA:miRNA (Figura 19.2). Já a fita miRNA* será degradada. Entretanto, alguns estudos têm demonstrado que miRNA* também pode funcionar como uma sequência de miRNA regular e controlar a expressão de genes-alvos específicos ${ }^{56}$.

A sequência de um miRNA maduro pode variar entre 19 a 24 nt e atua silenciando genes pós-transcricionalmente, através do pareamento com a sequência do mRNA-alvo, levando à clivagem ou à repressão traducional 
deste $^{57,58}$. Além disso, um mesmo miRNA maduro pode apresentar sequências que variam de um a dois nucleotídeos no seu comprimento. Essas populações de miRNAs são chamadas de isomiRNAs, o que significa isoforma de um miRNA. A origem dessas variantes de miRNAs ainda não está elucidada. Alguns autores acreditam que elas ocorram devido a um erro de clivagem da DCL1 durante o processamento do pré-miRNA ${ }^{56,59}$; entretanto, existem opiniões divergentes quanto a essa teoria. Como descrito anteriormente, os processos de biogênese e ação de miRNAs requerem a combinação e interações físicas de várias enzimas e/ou proteínas, como as proteínas DCL1, SE (proteína SERRATE, a qual contém motivos C2H2-zinc finger), CBC (cap-binding complex), AGO, RDPs, RNA belicase SDE3, HYL1 e CPL1 (C-terminal domain phosphatase-like 1$)^{46,60-64}$.

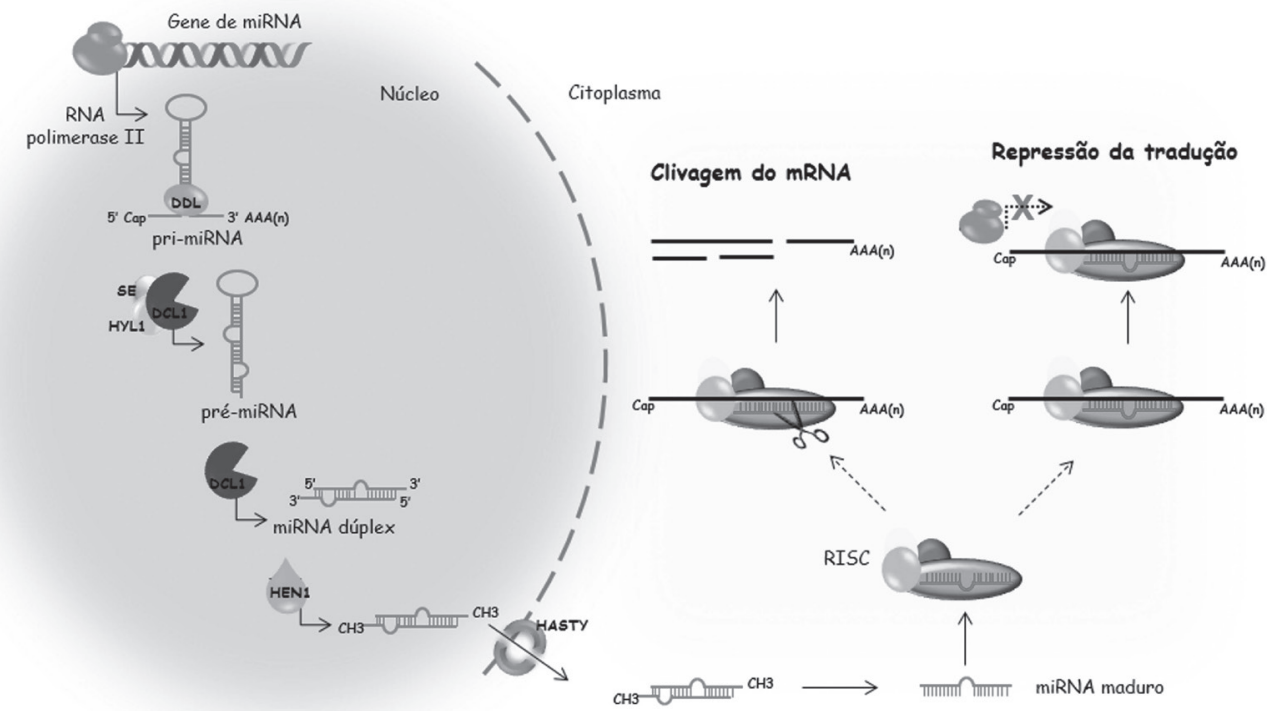

Figura 19.2 Biogênese e modos de ação dos miRNAs em plantas. Os pri-miRNAs são transcritos por uma RNA pol Il formando uma estrutura em formato de grampo poliadenilada em sua extremidade 3’. A essa estrutura liga-se a proteína DAWDLE (DDL), responsável por estabilizar o pri-miRNA até sua conversão em pré-miRNA. Esse processo conta com a ação combinada das proteínas SERRATE (SE), HYPONASTIC LEAVES 1 (HYLI) e DICER-LIKE 1 (DCL1). 0 pré-miRNA é então clivado novamente por uma DCL1, gerando um dúplex miRNA:miRNA* com extremidades $3^{\prime}$ salientes, que será exportado para o citoplasma pela proteína de membrana HASTY. Ambas as sequências miRNA:miRNA* serão metiladas por uma metilase HEN1, protegendo as sequências da degradação via nucleases degradadoras de smRNAs (SDN). A fita guia de miRNA é então incorporada em proteínas AGO componentes do complexo RISC, formando o complexo miR-RISC e agindo no silenciamento gênico.

A perda de função de DCL1 e SE é geralmente letal e causa a morte da planta ainda nos primeiros estágios embrionários, uma vez que nenhum 
acúmulo de miRNA maduro é observado nas células vegetais ${ }^{65}$. Mutantes $d d l$ e $c b c$ também têm baixo acúmulo de miRNAs ${ }^{66}$. Entretanto, outras evidências sugerem que a proteína DDL pode ter outras funções além de participar da biogênese de miRNAs, uma vez que mutantes $d d l$ possuem anormalidades mais fortes no desenvolvimento da planta que $d c l 1$ mutantes ${ }^{67}$.

Outro estudo demonstrou que a perda de função do gene HASTY resultou apenas em um decréscimo de miRNAs no citoplasma, o que sugere que miRNAs podem também ser transportados por outros mecanismos ${ }^{68}$. Uma mutação do gene HYL1, responsável pela proteína que atua em conjunto com DCL1 na primeira fase de processamento do pri-miRNA, também levou à alteração do desenvolvimento foliar, além de afetar a dominância apical e a sensibilidade hormonal em Arabidopsis. Essas plantas apresentaram alta sensibilidade ao ácido abscísico e baixa sensibilidade à citocina e à auxina ${ }^{69,70}$.

\subsection{3 tasiRNAs}

Em plantas, existem genes TAS, os quais são transcritos por uma RNA polimerase II em longos RNAs denominados tasiRNAs primários ${ }^{71,72}$. Esses transcritos são reconhecidos e clivados por miRNAs associados a proteínas AGO1 ou AGO7 (dependendo do miRNA). Entretanto, em vez de serem silenciados, esses transcritos de RNA não codificante clivados são usados como molde para a síntese de RNAs fita dupla (dsRNA) através da ação de uma RNA polimerase dependente de RNA (RdRp-RDR6), com o auxílio de uma proteína supressora de silenciamento gênico (suppressor of gene silencing 3 - SGS3). Os dsRNAs são reconhecidos e clivados por enzimas DCL4 e processados em pequenos RNAs de $21 \mathrm{nt}$, os quais serão denominados tasiRNAs. Os tasiRNAs vão associar-se ao complexo RISC e silenciar seus alvos (Figura 19.3).

Existem quatro famílias de tasiRNAs. As famílias recebem seus nomes conforme a localização dos genes TAS a partir dos quais estes foram transcritos. As famílias TAS1, TAS2 e TAS4 codificam mRNAs com um sítio de clivagem, enquanto TAS3 possui dois sítios. Os transcritos TAS1 e TAS2 são alvos do microRNA miR173, e TAS4 do microRNA miR828, e todos são clivados por AGO1. Já TAS3 é reconhecido pelo miR390 em dois sítios distintos, sendo que a clivagem é mediada por AGO7.

A ação regulatória mais proeminente dos tasiRNAs é o controle de fatores transcricionais responsivos à auxina (auxin response factors - ARFs), 


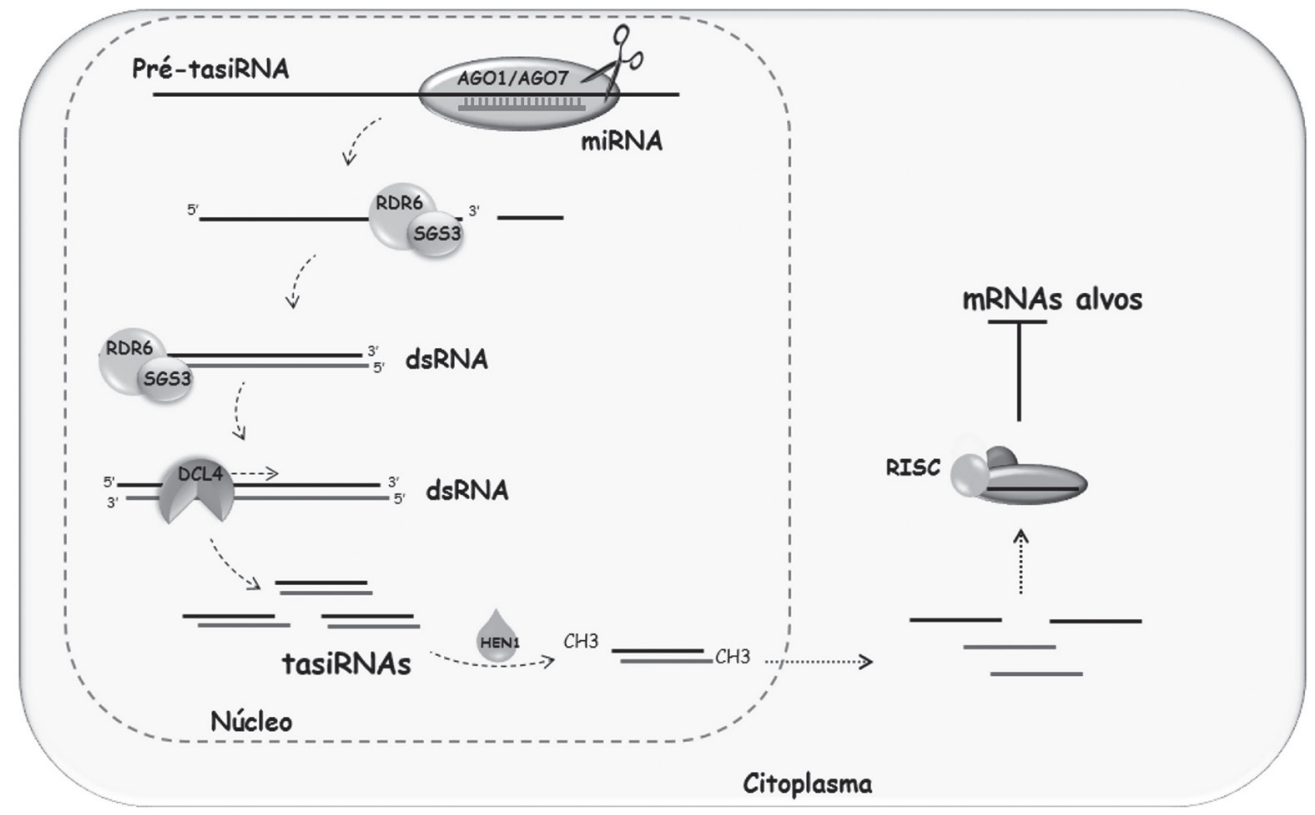

Figura 19.3 Geração de trans-acting siRNAs (tasiRNAs). Transcritos gerados a partir de loci TAS são reconhecidos e clivados por miRNAs associados a proteínas argonauta (AGOI ou AG07). Os fragmentos originados são estabilizados pelas proteínas SGS3 e utilizados como molde por uma RNA polimerase dependente de RNA (RdRp-RDR6) para a síntese de RNAs de fita dupla (dsRNA). Esses dsRNA serão reconhecidos e clivados por uma DCL4, originando tasiRNAs que podem associar-se ao complexo RISC, levando à regulação de seus alvos.

que participam da via de sinalização do hormônio auxina, o qual desempenha um papel central no desenvolvimento das plantas.

\subsection{4 tRFs}

Os RNAs transportadores ou tRNAs são uma classe de RNA não codificante, ubíquos e necessários para a leitura do código genético e subsequente síntese proteica. Os tRNAs são transcritos por RNAs polimerase III em pré-tRNAs, os quais são processados por uma RNAse P, a qual cliva uma sequência 5' leader, e por uma RNAse Z, a qual retira uma sequência 3' trailer. Após esse processamento, ocorrem modificações de bases, tais como adição de pseudouridina e adição de um trinucleotídeo CCA à extremidade 3', a qual é posteriormente utilizada para acoplamento do aminoácido, resultando no tRNA ativado ou maduro. 
Recentemente, uma nova classe de pequenos RNAs foi identificada a partir de culturas celulares humanas, e foi denominada de fragmentos derivados de RNA transportador (transfer RNA-derived fragments - tRFs) ${ }^{73}$, os quais possuem tamanho entre 18 a 22 nucleotídeos. Um tRNA pode originar três tipos de tRFs, os quais são nominados conforme a posição de origem no RNA transportador, podendo ser tRFs-1 originado pela liberação da extremidade 3' do pré-tRNA pela tRNAse Z; tRFs-5', originados da extremidade 5' do tRNA; e tRFs-3', produzidos a partir da extremidade 3' do tRNA maduro, isto é, após a adição do trinucleotídeo CCA (Figura 19.4).

Trabalhos recentes demonstraram a existência de tRFS em plantas. Por exemplo, em Arabidopsis, foram identificados tRFs provenientes da porção 5'do tRNA AspGTC e tRFS das porções 5' e 3' CCA do tRNA GlyTCC, sendo superexpressos em tecidos e raízes submetidos à privação de fosfato ${ }^{74}$. Em arroz, $\mathrm{tRF}$ provenientes do terminal 5' do tRNA-AlaAGC e -ProCGG demonstraram ser diferencialmente expressos em tecidos foliares e calos ${ }^{3}$. Já em cevada, tRF proveniente de tRNA-HisGTG foi o mais abundante de todos os tipos de sRNAs ${ }^{75}$. Embora o modo de ação do tRFS ainda não esteja bem esclarecido, um recente trabalho realizado em Arabidopsis demonstrou que esses sRNAs ligam a enzima AGO, indicando que talvez possam regular seus alvos via complexo RISC ${ }^{76}$.

\subsection{METODOLOGIA DE QUANTIFICAC̣ÃO DE sRNAs: RT-qPCR}

A transcrição reversa associada à reação em cadeia da polimerase quantitativa (RT-qPCR) literalmente revolucionou o estudo da expressão gênica. Na reação de RT-qPCR, o RNA molde é duplicado com a geração de uma fita de DNA complementar (cDNA) através da enzima transcriptase reversa. A sequência de cDNA de interesse é então amplificada exponencialmente usando qPCR, também chamada de PCR em tempo real.

O desenvolvimento de químicas modernas e plataformas de instrumentação que possibilitam a descoberta de produtos da PCR em tempo real conduziu à adoção difundida dessa técnica como o método de escolha para quantificar a mudança na expressão dos genes durante os últimos anos. Além disso, a PCR em tempo real tornou-se o método preferido para validar resultados obtidos por meio de análises que avaliam a expressão de gene em larga escala, como, por exemplo, sequenciamentos de última geração ${ }^{77}$. Dessa forma, qPCR também foi eleita como uma das metodologias 


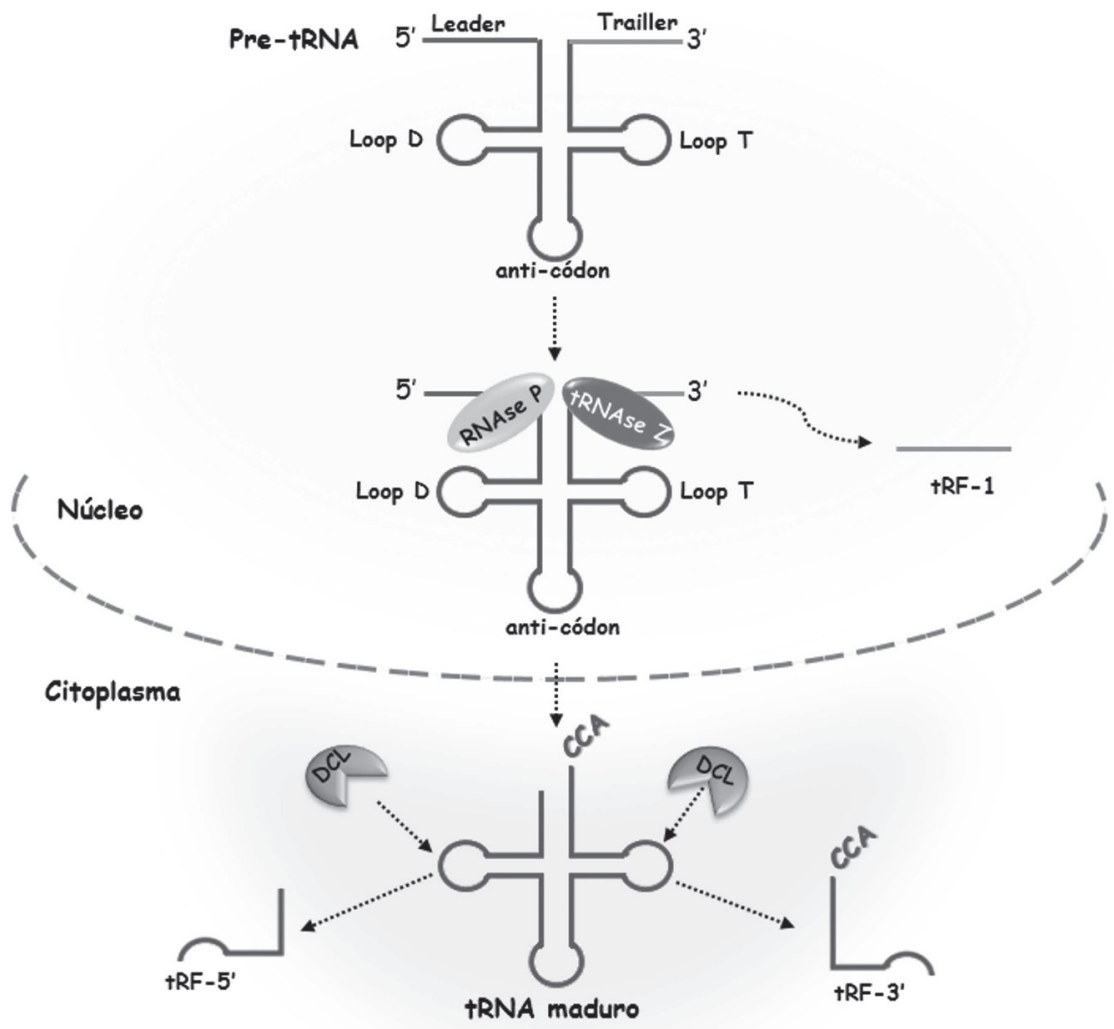

Figura 19.4 Biogênese de pequenos RNAs derivados de RNAs transportadores (tRFs). 0 RNA transportador (tRNA) é transcrito por uma RNA polimerase do tipo III em um precursor (pré-tRNA) contendo uma sequência leader no terminal $5^{\prime}$ e uma trailer na extremidade $3^{\prime}$. Ambas as sequências são removidas por ação de uma RNAse P e $Z$ respectivamente. A sequência trailer, liberada pela RNAse $Z$, consiste em um tRF do tipo I (tRF-1). Após esse processamento ocorre a adição de uma sequência CCA na extremidade 3', finalizando a maturação do tRNA. 0 tRNA maduro é então exportado para o citoplasma, onde poderá sofrer clivagens por enzimas do tipo DICER na porção do Loop T, liberando o tFR-3', ou no Loop D, originando tFR-5'. Os tRFs podem variar de 18 a 22 nt de comprimento.

preferidas para identificar diferenças globais na expressão de pequenos RNAs entre diferentes amostras.

Inicialmente o método de RT-qPCR foi aplicado para análises de miRNAs, e, dessa forma, algumas alterações na etapa de síntese do cDNA foram efetuadas para superar o desafio que era transcrever uma fita complementar relativa a pequenas sequências de RNA, que além de estarem presentes como sequências maduras, ainda poderiam ser detectadas nos transcritos primários e precursores destas. Neste cenário, foram desenvolvidas duas 
metodologias para síntese do cDNA de miRNAs, as quais passaram a ser também utilizadas nas análises de expressão de outras classes de pequenos RNAs. Como os trabalhos foram inicialmente realizados com miRNAs, a seção a seguir refere-se a miRNAs, mas salienta-se que tais trabalhos podem ser aplicados a outros sRNAs.

\subsection{Síntese de cDNA}

O primeiro passo na qPCR de miRNAs é uma conversão acurada e completa do RNA em um DNA complementar (cDNA) através da transcrição reversa. Entretanto, este passo não é tão simples, devido: (1) ao tamanho limitado da fita molde (aproximadamente $22 \mathrm{nt}$ ), (2) à inexistência de uma sequência comum para utilizar no enriquecimento e amplificação dos miRNAs; e (3) ao fato de a sequência madura do miRNA estar presente nos pri e pré-miRNAs.

Até o momento, duas diferentes abordagens para sintetizar o transcrito reverso de miRNAs têm sido utilizadas. $\mathrm{Na}$ primeira abordagem, miRNAs são transcritos reversamente através de oligonucleotídeos específicos para cada miRNA, método também conhecido por stem-loop ${ }^{55}$. $\mathrm{Na}$ segunda metodologia, uma cauda contendo uma sequência comum é adicionada a todos os miRNAs, e estes são transcritos reversamente através de um oligo reverso comum $^{78}$. A seguir, ambas as metodologias serão discutidas.

\subsubsection{Método stem-loop}

Nesta metodologia, a amplificação de cada miRNA é realizada utilizando três oligonucleotídeos:

- um oligonucleotídeo stem-loop, o qual consiste em 44 nucleotídeos fixos que formam uma haste (dois braços pareados) e um loop (5, GTCGTATCCAGTGCAGGGTCCGAGGTATTCGCACTGGATACGACNNNNNN 3') e seis nucleotídeos adicionais complementares à região 3' da porção terminal do miRNA maduro;

- um oligonucleotídeo direto específico, o qual é idêntico à sequência completa do miRNA maduro e que será utilizado na reação de qPCR; 
- um oligonucleotídeo universal reverso, uma sequência conservada ( $5^{\prime}$ GTGCAGGGTCCGAGGT 3') e que será empregada nas reações de qPCR de distintos miRNAs. O oligo universal reverso hibridizará na região correspondente ao loop do transcrito reverso.

A complexidade dos oligonucleotídeos stem-loop aumenta a especificidade da reação, uma vez que ocorre uma diminuição do anelamento do oligo às sequências de pri e pré-miRNAs. Já os oligonucleotídeos lineares não apresentam essa especificidade e podem anelar tanto nos miRNAs maduros quanto em seus precursores; consequentemente, os passos de anelamento e a transcrição reversa devem ser otimizados para prevenir a interação entre esses oligos e os pri e pré-miRNAs. Uma representação esquemática dos passos envolvidos na síntese de cDNA pelo método stem-loop pode ser observada na Figura 19.5A.

\subsubsection{Método poliA}

Uma abordagem alternativa é a extensão da porção terminal 3' do miRNA através da adição de uma sequência polimérica única e comum. Nesse caso, são adicionados nucleotídeos de adenina ou timina via ação da terminal nucletidil transferase de Escherichia coli ${ }^{78}$. Um oligonucleotídeo consistindo em uma sequência oligo-dT, contendo por sua vez uma sequência à qual se ligará um oligo universal na sua posição 5' é, então, utilizado para a transcrição reversa e para amplificar as sequências-alvos durante a qPCR.

A porção de dTs entre o miRNA e a sequência universal do oligo dT é definida utilizando sequências degeneradas no terminal 5' do oligonucleotídeo, o qual ancora o oligo ao terminal 3' do miRNA.

\subsubsection{Detecção dos produtos da qPCR}

O princípio da qPCR está baseado na detecção, em tempo real, de uma molécula fluorescente repórter cuja intensidade do sinal emitido é correlacionada à quantidade de DNA presente em cada ciclo de amplificação ${ }^{79,80}$. Existe uma gama de fluoróforos utilizados em reações de qPCR; entretanto, nas que envolvem amplificação de miRNAs, os mais amplamente utilizados são SYBR Green I e sondas TaqMan. Estão disponíveis no mercado dois tipos de SYBR Green, SYBR Green I e II. Enquanto SYBR Green I liga-se 
preferencialmente ao DNA dupla fita (do inglês double stranded DNA dsDNA), SYBR Green II se liga ao RNA. Neste capítulo, SYBR Green se refere a SYBR Green I.

\subsubsection{Detecção de produtos da qPCR utilizando SYBR Green}

O SYBR Green é uma molécula intercalante cuja fluorescência aumenta aproximadamente cem vezes apenas sob associação com dsDNA, e essa propriedade é utilizada para detectar os produtos de amplificação acumulados durante os ciclos da PCR. É importante salientar que o SYBR Green não consegue discriminar entre diferentes produtos da PCR e liga-se a todos os dsDNAs, incluindo dímeros de oligonucleotídeos ${ }^{81}$. Essa característica limita uma detecção acurada da sequência-alvo e requer metodologias que acessem a especificidade dos produtos gerados pela amplificação. Entretanto, o uso de SYBR Green permite realizar uma análise do ponto de melting, também chamada de análise de curva de dissociação, um importante passo para monitorar a homogeneidade dos produtos de $\mathrm{qPCR}^{79}$.

Durante a curva de melting, a intensidade da fluorescência do SYBR Green que está intercalado nos produtos da PCR é anotada durante um período em que a temperatura de início é de $65{ }^{\circ} \mathrm{C}$ e sofre pequenos aumentos até atingir $95{ }^{\circ} \mathrm{C}$. Esse aumento gradual da temperatura desnatura o dsDNA, o que ocasiona uma consequente redução do sinal de fluorescência, a qual será detectada por um queda acentuada na intensidade do sinal quando ambas as fitas de DNA estiverem completamente separadas. Como a temperatura de melting (Tm) de um DNA fita dupla é dependente do comprimento e composição nucleotídica da sequência, o número de inflexões na curva de melting indica o número de produtos da PCR (incluindo dímeros de oligonucleotídeos) gerados. Uma curva de dissociação aceitável apresenta um pico único, isto é, um único produto da PCR, enquanto a ocorrência de picos múltiplos indica a presença de produtos de amplificação não específicos ${ }^{79}$.

O emprego de SYBR Green durante RT-qPCR tem sido comprovado como um eficiente método para a detecção de produtos de expressão de miRNAs por alguns autores ${ }^{78,82}$. Por exemplo, na Figura 19.5B, estão demonstrados os gráficos de amplificação e as curvas de melting de dois miRNAs de soja relacionados: miR166a (5' TCGGACCAGGCTTCATTCCCC 3') e miR166de (5' TCGGACCAGGCTTCATTCCCG 3'). Esses miRNAs se diferenciam por apenas um nucleotídeo na extremidade 3', e mesmo com essa 

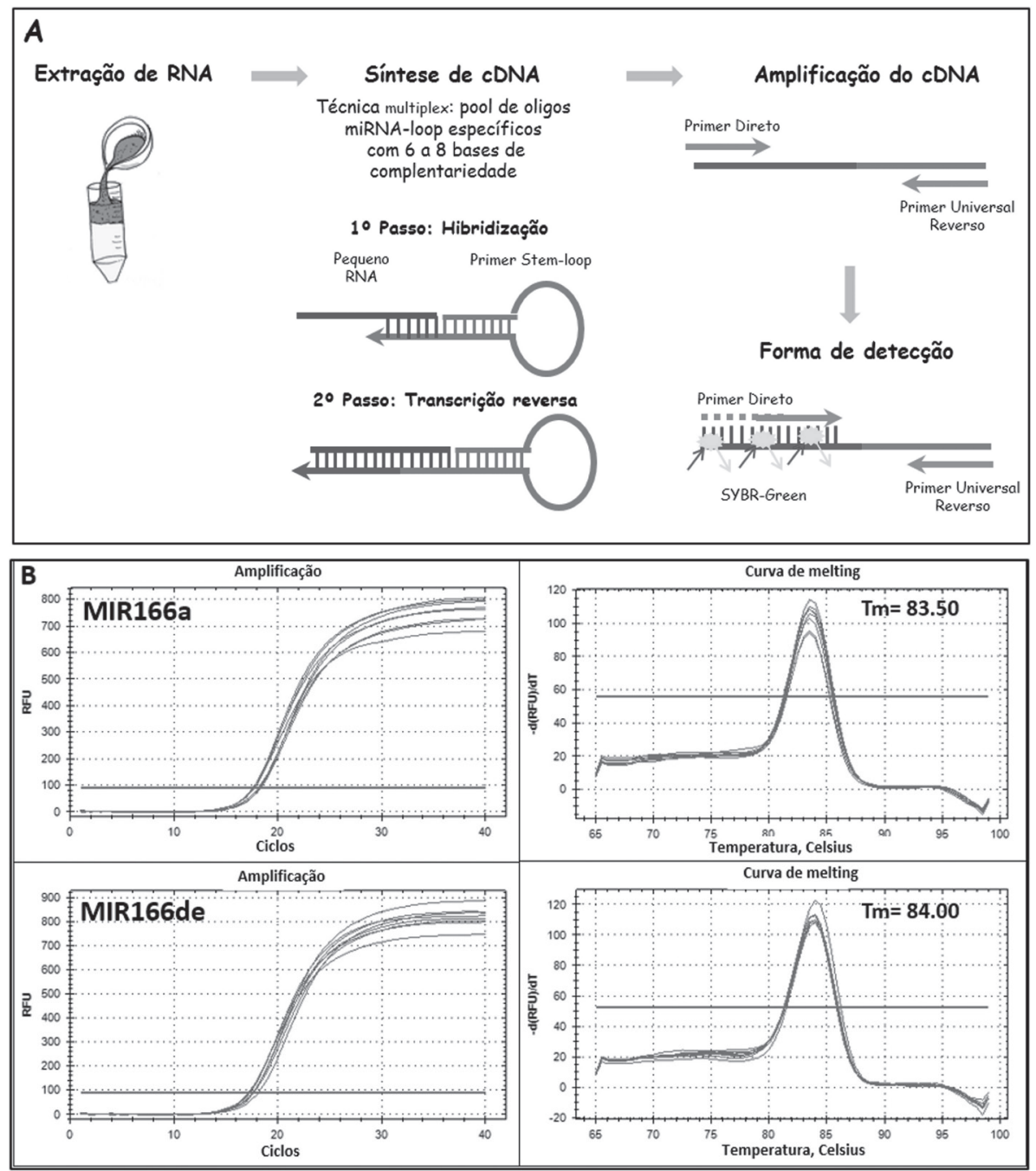

Figura 19.5 Metodologia de quantificação de pequenos RNAs através da RT-qPCR. (A) Representação esquemática da RT-qPCR utilizando oligonucleotídeos stem-loop e o fluoróforo SYBR Green: após a extração do RNA total é realizada a síntese da fita complementar (cDNA) por transcrição reversa. Nessa fase é preparado um pool com vários oligos stem-loop, possibilitando a síntese de cDNAs para vários sRNAs distintos em uma única reação. Os oligos stem-loop se ligam a região $3^{\prime}$ terminal da sequência de pequeno RNA maduro, 0 qual será transcrito reversamente por uma transcriptase reversa. Então, os transcritos reversos serão quantificados utilizando um fluoróforo SYBR Green, o qual possui a capacidade de intercalar DNA de fita dupla. Para a amplificação dos transcritos reversos são utilizados oligos diretos (idênticos à sequência madura do pequeno RNA) e o oligo universal reverso (correspondente a uma região conservada entre todos os oligos stem-loop). (B) Exemplos de gráficos da qPCR em tempo real para dois miRNAs de soja, miR166a e miR166de, utilizando 0 método stem-loop e o fluoróforo SYBR Green. São observadas as completas amplificações, bem como as distintas curvas de melting para ambos os miRNAs, os quais possuem sequências quase idênticas, comprovando a capacidade de alta especificidade dessa metodologia. 
ampla similaridade, durante a curva de dissociação foram observados dois picos únicos distintos entre esses miRNAs testados, demonstrando a alta especificidade da amplificação.

\subsubsection{Detecção de produtos da qPCR utilizando TaqMan}

Outra possibilidade de detecção dos produtos amplificados durante a qPCR é o emprego das sonda TaqMan. Essas sondas são marcadas em cada extremidade por um fluoróforo repórter (molécula que emite luz) e um quencher (molécula capaz de captar a energia do fluoróforo em forma de luz e dissipá-la tanto na forma de luz quanto de calor). A proximidade do fluoróforo repórter com a sua molécula quencher previne a emissão de fluorescência. Entretanto, durante a PCR em tempo real a sonda TaqMan hibridiza com a fita simples de cDNA. No processo de amplificação a sonda TaqMan é degradada devido à atividade de exonuclease 5' $\rightarrow$ 3' da enzima Taq DNA polimerase, separando o quencher do fluoróforo durante a extensão, o que resulta em um aumento da intensidade da fluorescência. Dessa forma, durante o processo de qPCR a emissão da fluorescência é aumentada de forma exponencial. Esse aumento da fluorescência ocorre apenas quando a sonda hibridiza e é degradada simultaneamente à amplificação da sequência-alvo estabelecida. Cabe salientar que embora os dímeros de oligonucleotídeos, bem como produtos inespecíficos gerados durante a amplificação, não emitam qualquer sinal de fluorescência, esses produtos irão afetar negativamente tanto a eficiência quanto a sensibilidade da reação de qPCR.

\subsubsection{Passo a passo: protocolo da RT-qPCR por stem-loop}

Passo 1: síntese de cDNA

Os oligonucleotídeos stem-loop de todos os miRNAs a serem testados são agrupados em uma mesma reação, para a síntese de cDNA multiplex, que ocorre em duas etapas:

I) Hibridização dos oligonucleotídeos stem-loop com o RNA total, conforme a reação a seguir: 


\begin{tabular}{cc}
\hline RNA total & 0,1 a $2 \mu g$ \\
\hline Mix de oligonucleotídeos stem-loop (0,5 $\mu \mathrm{M}$ cada) & $1 \mu \mathrm{L}$ \\
\hline $\mathrm{H}_{2} \mathrm{O}$ & q.S.p \\
\hline Volume total & $10 \mu \mathrm{L}$
\end{tabular}

- Incubar a $70{ }^{\circ} \mathrm{C}$ por 5 minutos.

- Imediatamente transferir para banho de gelo.

II) Síntese da primeira fita de cDNA com a enzima transcriptase reversa RNAse $\mathrm{H}$ de M-MLV, conforme reação a seguir:

\begin{tabular}{cc}
\hline $\begin{array}{c}\text { Material da etapa I } \\
\text { Tampão 5X M-MLV RT }\end{array}$ & $\begin{array}{c}10 \mu \mathrm{L} \\
6 \mu \mathrm{L}\end{array}$ \\
\hline dNTP (5mM) & $2 \mu \mathrm{L}$ \\
\hline Enzima M-MLV RT (200U/ $\mu \mathrm{L})$ & $1 \mu \mathrm{L}$ \\
\hline $\mathrm{H}_{2} \mathrm{O}$ & $11 \mu \mathrm{L}$ \\
\hline Volume total & $30 \mu \mathrm{L}$ \\
\hline
\end{tabular}

- Incubar a reação a $40{ }^{\circ} \mathrm{C}$ por 60 minutos.

- Ao final, diluir a reação na proporção 1:10 com $\mathrm{H}_{2} \mathrm{O}$ (solução de estoque).

- Para solução trabalho, utilizar uma diluição 1:30 a 1:50.

- $\mathrm{O}$ cDNA deve ser armazenado a $-20^{\circ} \mathrm{C}$.

\section{Passo 2: qPCR}

Neste protocolo o fluoróforo de escolha para detectar o produto de amplificação será o SYBR Green I.

Para a amplificação em tubos de $200 \mu \mathrm{L}$ ou mesmo em placas de 96 poços (dependendo da escolha pessoal), as reações podem ser realizadas em um volume total de $20 \mu \mathrm{L}$.

Todos os reagentes empregados com as respectivas concentrações finais para cada reação estão descritos a seguir: 


\begin{tabular}{cc}
\hline CDNA (DILUÍDO 1:30) & $10 \mu \mathrm{L}$ \\
\hline & \\
\hline MIX & $10 \mu \mathrm{L}$ \\
\hline Tampão Taq DNA polimerase & $1 \mathrm{X}$ \\
\hline $\mathrm{MgCl}$ & $3 \mathrm{mM}$ \\
\hline dNTP & $25 \mu \mathrm{M}$ \\
\hline Oligonucleotídeo direto & $0,2 \mu \mathrm{M}$ \\
\hline Oligonucleotídeo universal reverso & $0,2 \mu \mathrm{M}$ \\
\hline SYBR Green I & $0,1 \mathrm{X}$ \\
\hline Enzima Taq DNA polimerase & $0,25 \mathrm{U}$ \\
\hline
\end{tabular}

As condições de amplificação são:

I) Ativação inicial da enzima Taq DNA polimerase por 5 minutos a $95^{\circ} \mathrm{C}$.

II) Desnaturação a $95^{\circ} \mathrm{C}$ por 15 segundos.

III) Hibridização a $60^{\circ} \mathrm{C}$ por 10 segundos.

IV) Elongação a $72{ }^{\circ} \mathrm{C}$ por 10 segundos.

V) Repetição dos passos II a IV por 40 ciclos.

A análise de curva de melting ou curva de dissociação deve ser realizada no final da PCR e programada para um aumento da temperatura de $65{ }^{\circ} \mathrm{C}$ a $99{ }^{\circ} \mathrm{C}$.

Embora a parte de análise de expressão de miRNAs não seja abordada neste capítulo, salienta-se que o método mais amplamente utilizado na análise de miRNAs é a quantificação relativa ${ }^{83}$ ou $2^{-\Delta \Delta C \mathrm{t}}$.

\subsection{APLICAC̣ÕES BIOTECNOLÓGICAS DOS PEQUENOS RNAS}

\subsubsection{Pequenos RNAs de interferência (siRNAs)}

Os pequenos RNAs de interferência (siRNAs) podem ser utilizados para estudos da função gênica ou obtenção de organismos com características especiais com base no silenciamento de genes de interesse. A estratégia básica utilizada é a geração de organismos geneticamente modificados que 
contêm transgenes na posição senso e antissenso. Esses transgenes são capazes de gerar RNAs dupla fita (dsRNAs) os quais serão clivados por enzimas DCL, gerando pequenos fragmentos de RNA fita simples, os chamados de siRNAs. A sequência antissenso de siRNA é acoplada ao complexo RISC e identificará o mRNA-alvo, levando a um silenciamento desse transcrito.

O uso de siRNAs pode ser uma ferramenta bastante eficaz para a investigação da função de genes uma vez que dsRNAs podem ser introduzidos nas células para induzir o silenciamento seletivo de genes específicos de interesse. Por outro lado, a RNAi também é considerada uma alternativa promissora para a manipulação de plantas com baixos níveis de toxinas, redução dos níveis de alérgenos, bem como resistência a patógenos e pragas (Figura 19.6) que acometem inúmeras plantas de interesse econômico.

Um exemplo que se tornou bastante famoso na aplicação de RNAi para o controle de pragas foi o milho desenvolvido pela empresa Monsanto para controle da lagarta-da-raiz (Diabrotica virgifera LeConte) ${ }^{84}$. A companhia

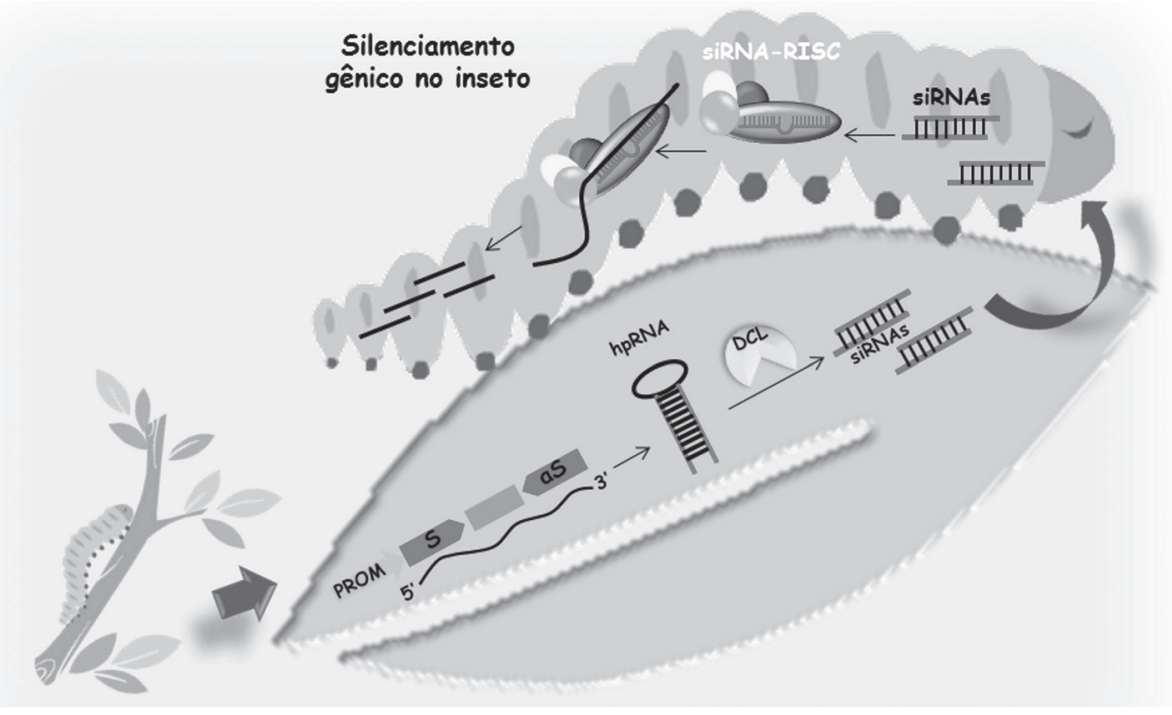

Figura 19.6 Exemplo de aplicação biotecnológica utilizando pequenos RNAs de interferência (siRNAs). Produção de uma planta transgênica contendo uma construção com sequências senso (S) e antissenso (AS) sob o controle de um promotor (PROM), as quais possuem homologia com uma sequência específica de algum gene de interesse do organismo-alvo, neste caso um inseto-praga. 0 transcrito do transgene inserido na planta se organizará em estruturas na forma de um grampo (hpRNA) que serão processadas pela maquinaria de biogênese de siRNAs da planta (DCL), produzindo siRNAs. Ao se alimentar da planta transgênica, o inseto-alvo ingere os siRNA capazes de se hibridizar a transcritos vitais ao inseto, os quais serão silenciados, levando o inseto à morte. Essa metodologia permite uma forma de controle específica a determinado organismo por parte da planta. 
desenvolveu um milho expressando dsRNAs que tinham por alvo o transcrito da ATPase vacuolar de D. virgifera. A ingestão desse milho pelas larvas do coleóptero levaram a uma alta taxa de mortalidade, superando aquela causada pelo milho $\mathrm{Bt}$ (milho transgênico expressando proteínas inseticidas de Bacillus thuringiensis), o qual também é empregado para o controle de D. virgifera. A demonstração do controle de um inseto-praga através do fornecimento oral de dsRNAs foi um marco para biotecnologia da RNAi aplicada ao melhoramento de plantas de interesse agronômico.

\subsubsection{Silenciamento gênico induzido por vírus (VIGS)}

O termo "silenciamento gênico induzido por vírus", ou VIGS, foi primeiramente empregado por A. Van Kammen em 1997, ao descrever o evento de resistência a infecções virais encontrado em plantas ${ }^{85}$. Plantas infectadas por muitos vírus induzem uma defesa mediada por RNA, a qual tem por alvos RNAs virais e quaisquer outros produtos de RNA transgênico inserido nelas ${ }^{86}$. Devido a essa característica, o mecanismo de VIGS originou uma poderosa ferramenta para suprimir a expressão de genes de interesse em plantas ${ }^{87,88}$.

Como um método de silenciamento gênico, VIGS tem várias vantagens como, por exemplo: rapidez, supressão transiente da expressão gênica e envolvimento da clonagem de fragmentos curtos do gene-alvo a ser silenciado. Como uma abordagem de genética reversa, VIGS promove o silenciamento dos alvos de uma forma sequência-específica. O mecanismo de silenciamento induzido por sRNAs também age em nível de VIGS, no qual uma sequência de siRNAs de 21 a 25 nt guia uma clivagem específica ou promove a supressão dos mRNAs-alvos pós-transcricionalmente ${ }^{2,89}$. O processo de silenciamento ocorre da mesma forma como em outros sRNAs, ou seja, os siRNAs são processados a partir de dsRNA por uma enzima DCL, e são então incorporados ao complexo RISC. Desta forma, o complexo RISC carregado com siRNAs regula transcritos com sequência contendo alta complementariedade com a sequência do siRNA ${ }^{57}$.

Os dsRNAs podem ser originados em plantas infectadas durante a replicação das fitas simples de sentido positivo de vírus de RNA (ssRNA) no citoplasma ${ }^{90}$. Já dsRNAs de transgenes podem ser gerados a partir da ação de RDRps do hospedeiro' ${ }^{91}$.

Com o potencial de silenciamento gênico comprovado, alguns vírus começaram a ser modificados a fim de silenciar genes de interesse. $\mathrm{O}$ primeiro 
vírus a ser modificado foi o tobacco mosaic virus (TMV), o qual recebeu um gene da enzima fitoeno dessaturase $(p d s)$ de Nicotiana benthamiana, e efetivamente silenciou esse gene endógeno quando introduzido na planta ${ }^{92}$.

A partir da comprovada eficiência e especificidade observada durante o processo de VIGS, outros vírus começaram a ser modificados, gerando novos vetores virais com potencial uso em plantas. Exemplos destes são: tobacco rattle virus (TRV) ${ }^{93}$, turnip yellow mosaic virus (TYMV) ${ }^{94}$, potato virus $X$ $(\mathrm{PVX})^{95}$ e barley strip mosaic virus (BSMV) ${ }^{96}$.

\subsection{3 microRNAs artificiais (amiRNAs)}

A construção de cassetes de DNA para expressão de microRNAs artificiais (amiRNAs) tem sido utilizada como uma forma alternativa de silenciamento gênico altamente específico e eficiente em várias espécies de plantas ${ }^{\text {97-99. }}$.

Essa metodologia baseia-se na produção de sequências de amiRNAs com 21 nucleotídeos, os quais podem ser geneticamente modificados e atuar como silenciadores específicos de um ou de múltiplos genes. Uma vez selecionado o gene-alvo a ser silenciado, sequências complementares reversas serão escolhidas e introduzidas em estruturas de precursores de miRNAs endógenos ao organismo de interesse. Quando o precursor, contendo as sequências de amiRNA, for introduzido no organismo, a produção desses amiRNAs seguirá a via canônica de processamento de miRNAs.

Plantas transgênicas contendo construções de amiRNA sob o controle de um promotor constitutivo apresentam um processamento preciso do amiRNA, bem como uma repressão específica e eficiente do transcrito-alvo de interesse $e^{97,99,100}$. Em arroz já foi observado que o transgene de amiRNA é estavelmente herdado e permanece ativo nas progênies, demonstrando ter uma ótima aplicação no melhoramento molecular de plantas ${ }^{99,100}$. Essas características fazem dos amiRNAs uma ferramenta ideal para a repressão de genes de interesse.

\subsubsection{Mimetização de alvos (target mimicry)}

Esta estratégia baseia-se em um mecanismo natural de regulação da expressão gênica encontrado em plantas. Por exemplo, há certos miRNAs que possuem dois tipos de transcritos alvos: um que possui um sítio totalmente complementar à sequência do miRNA, o que levaria à clivagem e 
degradação destes; e um segundo alvo que não pareia perfeitamente com a sequência do miRNA, o que ocasionaria apenas uma hibridização sem clivagem deste mRNA. Este segundo mRNA foi denominado de mimetizador de alvo canônico, ou, do inglês, target mimic ${ }^{101}$.

O primeiro caso de mimetização de alvos foi descrito em 2007 em $A$. thaliana, em um trabalho cujos autores observaram que certos miRNAs possuíam alvos que eram degradados e outros aos quais estes miRNAs apenas se ligavam e lá permaneciam sequestrados ${ }^{101}$. Um exemplo é o caso do transcrito IPS1 (induced by phosphate starvationv1), que possui um sítio complementar ao microRNA, miR399, com uma incompatibilidade (erro) na região central (de 11 a $13 \mathrm{nt}$ ). Embora isso permita que o miR399 ligue-se à IPS1, ele é incapaz de clivar esse alvo, mas, ao mesmo tempo, miR399 está colapsado à IPS1. Dessa forma, PHO2, um alvo genuíno do miR399, acaba escapando da supressão por miR399 até mesmo nos casos em que esse miRNA está presente em altos níveis. Quando a sequência de IPS1 foi mutada, permitindo que miR399 se ligasse com perfeita complementaridade, observou-se a degradação de IPS1.

O mecanismo de mimetização de alvos apoia-se na ideia de que quando vários alvos estão presentes, alguns serão favorecidos em detrimento de outros, e tal fenômeno pode ser governado pela força com que o miRNA se liga ao seu alvo.

\subsection{CONCLUSÕES}

As pesquisas sobre sRNAs e o mecanismo de RNAi em plantas têm avançado rapidamente desde a sua descoberta nos anos 1990. Esse campo da biologia experimenta uma rápida expansão, e um significativo conhecimento foi sendo acumulado nos últimos anos. Por exemplo, atualmente, várias classes de sRNAs já foram estabelecidas, bem como os fatores e cofatores que estão envolvidos na biogênese e funcionamento desses RNAs. Além disso, o aprimoramento das formas de uso do mecanismo de RNAi, levou ao desenvolvimento de várias ferramentas biotecnológicas para serem aplicadas com o objetivo de silenciar genes de interesse. Neste capítulo reunimos informações sobre as classes mais proeminentes de sRNAs em plantas, bem como uma das metodologias mais amplamente aplicadas para detecção desses sRNAs, a RT-qPCR, além de apresentar um panorama das possibilidades de aplicações de RNAi no ramo do melhoramento molecular de plantas. Contudo, embora o potencial do uso da via de interferência por RNA em plantas já esteja 
bem estabelecido, ainda assim existe a necessidade de aprofundar as pesquisas nesse campo. Uma forma é promover ensaios experimentais de longo prazo, a fim de avaliar a influência das culturas transgênicas com RNAi no ambiente onde estão sendo cultivadas, considerando todas as fases do ciclo ecológico, bem como a cadeia alimentar envolvida.

\subsection{PERSPECTIVAS FUTURAS}

Durante os últimos anos, os estudos focados no entendimento do mecanismo de RNAi possibilitaram o desenvolvimento de novas ferramentas biotecnológicas empregando sRNAs no melhoramento genético de plantas de interesse econômico.

O progresso biotecnológico observado na agroindústria teve como marco inicial plantas modificadas geneticamente com o intuito de obter maior resistência a insetos e herbicidas, seguido da manipulação de plantas para obter cultivares com enriquecimento nutricional. Nessa via, a interferência por RNA tende a levar a um novo grupo de plantas transgênicas, as quais são passíveis de melhorias tanto no que diz respeito a seus sistemas imunes (aumentando a resistência a vírus e patógenos) quanto na redução dos níveis de substâncias nocivas ou tóxicas aos consumidores.

Até o presente momento nenhuma planta contendo RNAi passou dos testes experimentais e foi liberada comercialmente. Entretanto, acredita-se que seja apenas uma questão de tempo, pois muitas culturas estão sendo manipuladas a fim de proporcionar consideráveis benefícios ao consumidor final. Um exemplo disso é o empenho das duas gigantes da produção de sementes, as multinacionais Monsanto e Dupont, que têm como objetivo o emprego de RNAi para a redução de gorduras trans no óleo de soja. A ideia de beneficiar diretamente a saúde do consumidor certamente auxiliará no crescimento da aceitação do público ao consumo de plantas geneticamente manipuladas.

Outro foco é a manipulação de plantas para a redução dos níveis de toxinas naturais existentes nestas. Por exemplo, sementes de algodão são ricas em proteínas da dieta humana, mas contêm naturalmente gossipol, um terpenoide tóxico, o que as torna impróprias para o consumo humano. Uma alternativa para sobrepujar esse problema seria a aplicação de RNAi a fim de silenciar a enzima delta-cadinene sintetase, a qual é um fator-chave na produção de gossipol. Além disso, a tecnologia de RNAi permite direcionar o silenciamento de uma forma tecido-específico, ou seja, o silenciamento só seria realizado na semente, visto que o gossipol participa da via de defesa 
contra pragas do algodão. Seguindo essa linha, outros candidatos a potencial tratamento com RNAi seriam tomates, a fim de reduzir os níveis de alérgenos concentrados no fruto; bem como o tabaco, com redução dos níveis de substâncias carcinogênicas encontradas nas folhas.

Uma das perspectivas mais excitantes na aplicação dos pequenos RNAs na manipulação gênica está chamando a atenção de pesquisadores de todas as áreas, da medicina ${ }^{102,103}$ ao melhoramento de plantas ${ }^{104-106}$. O sistema, chamado de repetições palindrômicas curtas regularmente espaçadas e aglomeradas (cluster regularly interspaced short palindromic repeats - CRISPR), explodiu em popularidade e está sendo visto como uma ferramenta de pesquisa altamente eficiente e precisa. A tecnologia CRISPR se baseia em uma estratégia de proteção utilizada por bactérias para detectar e remover DNA exógeno. A enzima de restrição Cas9 encontra seu alvo com a ajuda de uma sequência guia de RNA, fazendo com que essa nuclease seja capaz de editar a sequência-alvo. Notavelmente, já se tem demonstrado que as fitas guias de RNA podem ser alteradas, direcionando a ação de Cas9 para genes de interesse. $\mathrm{Na}$ área médica, essa tecnologia inovadora, de edição de genes, pretende remover mutações nocivas e trocá-las por DNA saudável, o que significaria a cura de inúmeras doenças causadas por SNPs. Testes em plantas já estão sendo iniciados, e recentemente um grupo da Universidade da Pensilvânia, testando a aplicação desse sistema em arroz, demonstrou que o sistema CRISPR-Cas pode ser explorado como uma poderosa ferramenta para atingir genes-alvos via pequenos RNAs guias e realizar precisa edição no genoma de plantas ${ }^{105}$.

Por último, outro ponto relevante a ser considerado quando do uso da tecnologia de RNAi é o risco de efeito off-target, isto é, de um sRNA silenciar outro transcrito diferente daquele para o qual foi projetado. No entanto, uma cuidadosa projeção dos transgenes que serão utilizados e a escolha de promotores tecidos-específicos podem diminuir este risco.

Apesar da recente descoberta, não há dúvidas de que a tecnologia que emprega o silenciamento através de sRNA é uma das ferramentas biotecnológicas mais promissoras para o melhoramento de plantas nos próximos anos. 


\section{REFERÊNCIAS}

1. Napoli C, Lemieux C, Jorgensen R. Introduction of a Chimeric Chalcone Synthase Gene into Petunia Results in Reversible Co-Suppression of Homologous Genes in trans. Plant Cell. 1990 Apr;2(4):279-89.

2. Fire A, Xu S, Montgomery MK, Kostas SA, Driver SE, Mello CC. Potent and specific genetic interference by double-stranded RNA in Caenorhabditis elegans. Nature. 1998 Feb 19;391(6669):806-11.

3. Chen CJ, Liu Q, Zhang YC, Qu LH, Chen YQ, Gautheret D. Genome-wide discovery and analysis of microRNAs and other small RNAs from rice embryogenic callus. RNA Biol. 2011 May-Jun;8(3):538-47.

4. Ecker JR, Davis RW. Inhibition of gene expression in plant cells by expression of antisense RNA. Proc Natl Acad Sci U S A. 1986 Aug;83(15):5372-6.

5. Van Blokland R, Van der Geest N, Mol J, Kooter J. Transgene-mediated suppression of chalcone synthase expression in Petunia bybrida results from an increase in RNA turnover. Plant J 1994;6:861-77.

6. Covey S, Al-Kaff N, Lángara A, Turner D. Plants combat infection by gene silencing. Nature 1997;385 (6619):781-2.

7. Ratcliff F, Harrison BD, Baulcombe DC. A similarity between viral defense and gene silencing in plants. Science. 1997 Jun 6;276(5318):1558-60.

8. Guo S, Kemphues KJ. par-1, a gene required for establishing polarity in C. elegans embryos, encodes a putative Ser/Thr kinase that is asymmetrically distributed. Cell. 1995 May 19;81(4):611-20.

9. Pal-Bhadra M, Bhadra U, Birchler JA. Cosuppression in Drosophila: gene silencing of Alcohol dehydrogenase by white-Adh transgenes is Polycomb dependent. Cell. 1997 Aug 8;90(3):479-90.

10. Baulcombe D. RNA silencing in plants. Nature. 2004 Sep 16;431(7006):356-63.

11. Llave C. Virus-derived small interfering RNAs at the core of plant-virus interactions. Trends Plant Sci. 2010 Dec;15(12):701-7.

12. Law JA, Jacobsen SE. Establishing, maintaining and modifying DNA methylation patterns in plants and animals. Nat Rev Genet. 2010 Mar;11(3):204-20.

13. Lee TF, Gurazada SG, Zhai J, Li S, Simon SA, Matzke MA, et al. RNA polymerase $\mathrm{V}$-dependent small RNAs in Arabidopsis originate from small, intergenic loci including most SINE repeats. Epigenetics. 2012 Jul;7(7):781-95.

14. Matzke M, Kanno T, Daxinger L, Huettel B, Matzke AJ. RNA-mediated chromatinbased silencing in plants. Curr Opin Cell Biol. 2009 Jun;21(3):367-76.

15. Lippman Z, Martienssen R. The role of RNA interference in heterochromatic silencing. Nature. 2004 Sep 16;431(7006):364-70. 
16. Pontes O, Li CF, Costa Nunes P, Haag J, Ream T, Vitins A, et al. The Arabidopsis chromatin-modifying nuclear siRNA pathway involves a nucleolar RNA processing center. Cell. 2006 Jul 14;126(1):79-92.

17. Zheng X, Zhu J, Kapoor A, Zhu JK. Role of Arabidopsis AGO6 in siRNA accumulation, DNA methylation and transcriptional gene silencing. EMBO J. 2007 Mar 21;26(6):1691-701.

18. Jamalkandi SA, Masoudi-Nejad A. Reconstruction of Arabidopsis thaliana fully integrated small RNA pathway. Funct Integr Genomics. 2009 Nov;9(4):419-32.

19. Borsani O, Zhu J, Verslues PE, Sunkar R, Zhu JK. Endogenous siRNAs derived from a pair of natural cis-antisense transcripts regulate salt tolerance in Arabidopsis. Cell. 2005 Dec 29;123(7):1279-91.

20. Katiyar-Agarwal S, Morgan R, Dahlbeck D, Borsani O, Villegas A Jr., Zhu JK, et al. A pathogen-inducible endogenous siRNA in plant immunity. Proc Natl Acad Sci U S A. 2006 Nov 21;103(47):18002-7.

21. Xie Z, Qi X. Diverse small RNA-directed silencing pathways in plants. Biochim Biophys Acta. 2008 Nov;1779(11):720-4.

22. Lee RC, Ambros V. An extensive class of small RNAs in Caenorhabditis elegans. Science. 2001 Oct 26;294(5543):862-4.

23. Park W, Li J, Song R, Messing J, Chen X. CARPEL FACTORY, a Dicer homolog, and HEN1, a novel protein, act in microRNA metabolism in Arabidopsis thaliana. Curr Biol. 2002 Sep 3;12(17):1484-95.

24. Reinhart BJ, Bartel DP. Small RNAs correspond to centromere heterochromatic repeats. Science. 2002 Sep 13;297(5588):1831.

25. Griffiths-Jones S. The microRNA Registry. Nucleic Acids Res. 2004 Jan 1;32(Database issue):D109-11.

26. Griffiths-Jones S. miRBase: the microRNA sequence database. Methods Mol Biol. 2006;342:129-38.

27. Griffiths-Jones S, Grocock RJ, van Dongen S, Bateman A, Enright AJ. miRBase: microRNA sequences, targets and gene nomenclature. Nucleic Acids Res. 2006 Jan 1;34(Database issue):D140-4.

28. Griffiths-Jones S, Saini HK, van Dongen S, Enright AJ. miRBase: tools for microRNA genomics. Nucleic Acids Res. 2008 Jan;36(Database issue):D154-8.

29. Kozomara A, Griffiths-Jones S. miRBase: integrating microRNA annotation and deep-sequencing data. Nucleic Acids Res. 2010 Jan;39(Database issue):D152-7.

30. Yang T, Xue L, An L. Functional diversity of miRNA in plants. Plant Science. 2007;172:423-32.

31. Lelandais-Briere C, Sorin C, Declerck M, Benslimane A, Crespi M, Hartmann

C. Small RNA diversity in plants and its impact in development. Curr Genomics. Mar;11(1):14-23. 
32. Lelandais-Briere C, Sorin C, Declerck M, Benslimane A, Crespi M, Hartmann C. Small RNA diversity in plants and its impact in development. Curr Genomics. 2010 Mar;11(1):14-23.

33. Liu Q, Chen Y-Q. Insights into the mechanism of plant development: interactions of miRNAs pathway with phytormone response. Biochemical and Biophysical Research Communications. 2009;384:1-5.

34. Chuck G, Candela H, Hake S. Big impacts by small RNAs in plant development. Curr Opin Plant Biol. 2009 Feb;12(1):81-6.

35. Katiyar-Agarwal S, Jin H. Role of small RNAs in host-microbe interactions. Annu Rev Phytopathol. Sep 8;48:225-46.

36. Lu YD, Gan QH, Chi XY, Qin S. Roles of microRNA in plant defense and virus offense interaction. Plant Cell Rep. 2008 Oct;27(10):1571-9.

37. Lu XY, Huang XL. Plant miRNAs and abiotic stress responses. Biochem Biophys Res Commun. 2008 Apr 11;368(3):458-62.

38. Shukla LI, Chinnusamy V, Sunkar R. The role of microRNAs and other endogenous small RNAs in plant stress responses. Biochim Biophys Acta. 2008 Nov;1779(11):743-8. 39. Sunkar R, Zhu JK. Novel and stress-regulated microRNAs and other small RNAs from Arabidopsis. Plant Cell. 2004 Aug;16(8):2001-19.

40. Bonnet E, Wuyts J, Rouze P, Van de Peer Y. Detection of 91 potential conserved plant microRNAs in Arabidopsis thaliana and Oryza sativa identifies important target genes. Proc Natl Acad Sci U S A. 2004 Aug 3;101(31):11511-6.

41. Wang XJ, Reyes JL, Chua NH, Gaasterland T. Prediction and identification of Arabidopsis thaliana microRNAs and their mRNA targets. Genome Biol. 2004;5(9):R65. 42. Wang JF, Zhou H, Chen YQ, Luo QJ, Qu LH. Identification of 20 microRNAs from Oryza sativa. Nucleic Acids Res. 2004;32(5):1688-95.

43. Jones-Rhoades MW, Bartel DP, Bartel B. MicroRNAS and their regulatory roles in plants. Annu Rev Plant Biol. 2006;57:19-53.

44. Lee Y, Kim M, Han J, Yeom KH, Lee S, Baek SH, et al. MicroRNA genes are transcribed by RNA polymerase II. EMBO J. 2004 Oct 13;23(20):4051-60.

45. Faller M, Guo F. MicroRNA biogenesis: there's more than one way to skin a cat. Biochim Biophys Acta. 2008 Nov;1779(11):663-7.

46. Kurihara Y, Takashi Y, Watanabe Y. The interaction between DCL1 and HYL1 is important for efficient and precise processing of pri-miRNA in plant microRNA biogenesis. RNA. 2006 Feb;12(2):206-12.

47. Meyers BC, Axtell MJ, Bartel B, Bartel DP, Baulcombe D, Bowman JL, et al. Criteria for annotation of plant MicroRNAs. Plant Cell. 2008 Dec;20(12):3186-90.

48. Zhang B, Pan X, Cannon CH, Cobb GP, Anderson TA. Conservation and divergence of plant microRNA genes. Plant J. 2006 Apr;46(2):243-59. 
49. Song QX, Liu YF, Hu XY, Zhang WK, Ma B, Chen SY, et al. Identification of miRNAs and their target genes in developing soybean seeds by deep sequencing. BMC Plant Biol. 2011;11:5.

50. Song L, Han MH, Lesicka J, Fedoroff N. Arabidopsis primary microRNA processing proteins HYL1 and DCL1 define a nuclear body distinct from the Cajal body. Proc Natl Acad Sci U S A. 2007 Mar 27;104(13):5437-42.

51. Ramachandran V, Chen X. Degradation of microRNAs by a family of exoribonucleases in Arabidopsis. Science. 2008 Sep 12;321(5895):1490-2.

52. Yu B, Yang Z, Li J, Minakhina S, Yang M, Padgett RW, et al. Methylation as a crucial step in plant microRNA biogenesis. Science. 2005 Feb 11;307(5711):932-5.

53. Li J, Yang Z, Yu B, Liu J, Chen X. Methylation protects miRNAs and siRNAs from a 3'-end uridylation activity in Arabidopsis. Curr Biol. 2005 Aug 23;15(16):1501-7.

54. Bollman KM, Aukerman MJ, Park MY, Hunter C, Berardini TZ, Poethig RS. HASTY, the Arabidopsis ortholog of exportin 5/MSN5, regulates phase change and morphogenesis. Development. 2003 Apr;130(8):1493-504.

55. Chen X. MicroRNA biogenesis and function in plants. FEBS Lett. 2005 Oct 31;579(26):5923-31.

56. Guo L, Lu Z. Global expression analysis of miRNA gene cluster and family based on isomiRs from deep sequencing data. Comput Biol Chem. 2009 Jun;34(3):165-71.

57. Bartel DP. MicroRNAs: genomics, biogenesis, mechanism, and function. Cell. 2004 Jan 23;116(2):281-97.

58. Bartel DP. MicroRNAs: target recognition and regulatory functions. Cell. 2009 Jan $23 ; 136(2): 215-33$.

59. Guo L, Lu Z. Global expression analysis of miRNA gene cluster and family based on isomiRs from deep sequencing data. Comput Biol Chem. Jun;34(3):165-71.

60. Manavella PA, Hagmann J, Ott F, Laubinger S, Franz M, Macek B, et al. FastForward Genetics Identifies Plant CPL Phosphatases as Regulators of miRNA Processing Factor HYL1. Cell. Nov 9;151(4):859-70.

61. Dalmay T, Horsefield R, Braunstein TH, Baulcombe DC. SDE3 encodes an RNA helicase required for post-transcriptional gene silencing in Arabidopsis. EMBO J. 2001 Apr 17;20(8):2069-78.

62. Fagard M, Boutet S, Morel JB, Bellini C, Vaucheret H. AGO1, QDE-2, and RDE-1 are related proteins required for post-transcriptional gene silencing in plants, quelling in fungi, and RNA interference in animals. Proc Natl Acad Sci U S A. 2000 Oct 10;97(21):11650-4.

63. Fang Y, Spector DL. Identification of nuclear dicing bodies containing proteins for microRNA biogenesis in living Arabidopsis plants. Curr Biol. 2007 May 1;17(9):818-23. 
64. Mourrain P, Beclin C, Vaucheret H. Are gene silencing mutants good tools for reliable transgene expression or reliable silencing of endogenous genes in plants? Genet Eng (N Y). 2000;22:155-70.

65. Xie Z, Kasschau KD, Carrington JC. Negative feedback regulation of DicerLike1 in Arabidopsis by microRNA-guided mRNA degradation. Curr Biol. 2003 Apr 29;13(9):784-9.

66. Kim S, Yang JY, Xu J, Jang IC, Prigge MJ, Chua NH. Two cap-binding proteins CBP20 and CBP80 are involved in processing primary MicroRNAs. Plant Cell Physiol. 2008 Nov;49(11):1634-44.

67. Yu B, Bi L, Zheng B, Ji L, Chevalier D, Agarwal M, et al. The FHA domain proteins DAWDLE in Arabidopsis and SNIP1 in humans act in small RNA biogenesis. Proc Natl Acad Sci U S A. 2008 Jul 22;105(29):10073-8.

68. Voinnet O. Origin, biogenesis, and activity of plant microRNAs. Cell. 2009 Feb 20;136(4):669-87.

69. Lu C, Fedoroff N. A mutation in the Arabidopsis HYL1 gene encoding a dsRNA binding protein affects responses to abscisic acid, auxin, and cytokinin. Plant Cell. 2000 Dec;12(12):2351-66.

70. Vazquez F, Vaucheret H, Rajagopalan R, Lepers C, Gasciolli V, Mallory AC, et al. Endogenous trans-acting siRNAs regulate the accumulation of Arabidopsis mRNAs. Mol Cell. 2004 Oct 8;16(1):69-79.

71. Fahlgren N, Montgomery TA, Howell MD, Allen E, Dvorak SK, Alexander AL, et al. Regulation of AUXIN RESPONSE FACTOR3 by TAS3 ta-siRNA affects developmental timing and patterning in Arabidopsis. Curr Biol. 2006 May 9;16(9):939-44.

72. Talmor-Neiman M, Stav R, Klipcan L, Buxdorf K, Baulcombe DC, Arazi T. Identification of trans-acting siRNAs in moss and an RNA-dependent RNA polymerase required for their biogenesis. Plant J. 2006 Nov;48(4):511-21.

73. Cole C, Sobala A, Lu C, Thatcher SR, Bowman A, Brown JW, et al. Filtering of deep sequencing data reveals the existence of abundant Dicer-dependent small RNAs derived from tRNAs. RNA. 2009 Dec;15(12):2147-60.

74. Hsieh LC, Lin SI, Shih AC, Chen JW, Lin WY, Tseng CY, et al. Uncovering small RNA-mediated responses to phosphate deficiency in Arabidopsis by deep sequencing. Plant Physiol. 2009 Dec;151(4):2120-32.

75. Hackenberg M, Huang PJ, Huang CY, Shi BJ, Gustafson P, Langridge P. A comprehensive expression profile of microRNAs and other classes of non-coding small RNAs in barley under phosphorous-deficient and -sufficient conditions. DNA Res. Apr;20(2):109-25.

76. Loss-Morais G, Waterhouse PM, Margis R. Description of plant tRNA-derived RNA fragments (tRFs) associated with argonaute and identification of their putative targets. Biol Direct.8:6. 
77. Bustin SA. Absolute quantification of mRNA using real-time reverse transcription polymerase chain reaction assays. J Mol Endocrinol. 2000 Oct;25(2):169-93.

78. Shi R, Chiang VL. Facile means for quantifying microRNA expression by real-time PCR. Biotechniques. 2005 Oct;39(4):519-25.

79. Benes V, Castoldi M. Expression profiling of microRNA using real-time quantitative PCR, how to use it and what is available. Methods. 2010 Apr;50(4):244-9.

80. Nolan T, Hands RE, Bustin SA. Quantification of mRNA using real-time RT-PCR. Nat Protoc. 2006;1(3):1559-82.

81. Zipper H, Brunner H, Bernhagen J, Vitzthum F. Investigations on DNA intercalation and surface binding by SYBR Green I, its structure determination and methodological implications. Nucleic Acids Res. 2004;32(12):e103.

82. Kulcheski FR, Marcelino-Guimaraes FC, Nepomuceno AL, Abdelnoor RV, Margis R. The use of microRNAs as reference genes for quantitative polymerase chain reaction in soybean. Anal Biochem. 2010 Nov 15;406(2):185-92.

83. Livak KJ, Schmittgen TD. Analysis of relative gene expression data using real-time quantitative PCR and the 2(-Delta Delta C(T)) Method. Methods. 2001 Dec;25(4):402-8. 84. Baum JA, Bogaert T, Clinton W, Heck GR, Feldmann P, Ilagan O, et al. Control of coleopteran insect pests through RNA interference. Nat Biotechnol. 2007 Nov;25(11):1322-6.

85. Van Kammen A. Virus-induced gene silencing in infectedand transgenic plants. Trends in Plant Science. 1997;2(11):409-11.

86. Voinnet O. RNA silencing as a plant immune system against viruses Trends in Genetics. 2001 17(8):449-59.

87. Baulcombe D. Fast forward genetics based on virus induced gene silencing. Current Opinion in Plant Biology. 1999;2(2):109-13.

88. Dinesh-Kumar S, Anandalakshmi R, Marathe R, Schi M, Liu Y. Virus-induced gene silencing. Methods in Molecular Biology. 2003;236:287-94.

89. Klahre U, Crété P, Leuenberger S, Iglesias V, Meins FJ. High molecular weight RNAs and small interferingRNAs induce systemic posttranscriptional gene silencing inplants,. Proceedings of the National Academy of Sciences of the United States of America. 2002;99(18):11981-6.

90. Voinnet O. RNA silencing as a plant immune system against viruses. Trends Genet. 2001 Aug;17(8):449-59.

91. Dalmay T, Hamilton A, Rudd S, Angell S, Baulcombe D. An RNA-dependent RNA polymerase gene in Arabidopsis is required for posttranscriptional gene silencing mediated by a transgene but not by a virus. Cell. 2000;101(5):543-53.

92. Kumagai MH, Donson J, della-Cioppa G, Harvey D, Hanley K, Grill LK. Cytoplasmic inhibition of carotenoid biosynthesis with virus-derived RNA. Proc Natl Acad Sci U S A. 1995 Feb 28;92(5):1679-83. 
93. Liu Y, Schiff M, Marathe R, Dinesh-Kumar SP. Tobacco Rar1, EDS1 and NPR1/ NIM1 like genes are required for $\mathrm{N}$-mediated resistance to tobacco mosaic virus. Plant J. 2002 May;30(4):415-29.

94. Pflieger S, Blanchet S, Camborde L, Drugeon G, Rousseau A, Noizet M, et al. Efficient virus-induced gene silencing in Arabidopsis using a 'one-step' TYMV-derived vector. Plant J. 2008 Nov;56(4):678-90.

95. Lu R, Malcuit I, Moffett P, Ruiz MT, Peart J, Wu AJ, et al. High throughput virusinduced gene silencing implicates heat shock protein 90 in plant disease resistance. EMBO J. 2003 Nov 3;22(21):5690-9.

96. Holzberg S, Brosio P, Gross C, Pogue GP. Barley stripe mosaic virus-induced gene silencing in a monocot plant. Plant J. 2002 May;30(3):315-27.

97. Khraiwesh B, Ossowski S, Weigel D, Reski R, Frank W. Specific gene silencing by artificial MicroRNAs in Physcomitrella patens: an alternative to targeted gene knockouts. Plant Physiol. 2008 Oct;148(2):684-93.

98. Schwab R, Ossowski S, Riester M, Warthmann N, Weigel D. Highly specific gene silencing by artificial microRNAs in Arabidopsis. Plant Cell. 2006 May;18(5):1121-33. 99. Warthmann N, Chen H, Ossowski S, Weigel D, Herve P. Highly specific gene silencing by artificial miRNAs in rice. PLoS One. 2008;3(3):e1829.

100. Zhou M, Luo H. MicroRNA-mediated gene regulation: potential applications for plant genetic engineering. Plant Mol Biol. 2013 Sep;83(1-2):59-75.

101. Franco-Zorrilla JM, Valli A, Todesco M, Mateos I, Puga MI, Rubio-Somoza I, et al. Target mimicry provides a new mechanism for regulation of microRNA activity. Nat Genet. 2007 Aug;39(8):1033-7.

102. Shalem O, Sanjana NE, Hartenian E, Shi X, Scott DA, Mikkelson T, et al. Genome-Scale CRISPR-Cas9 Knockout Screening in Human Cells. Science. 2014 Jan 3; 343(6166): 84-87.

103. Wang T, Wei JJ, Sabatini DM, Lander ES. Genetic Screens in Human Cells Using the CRISPR/Cas9 System. Science. 2014 Jan 3; 343(6166): 80-84.

104. Shan Q, Wang Y, Li J, Zhang Y, Chen K, Liang Z, et al. Targeted genome modification of crop plants using a CRISPR-Cas system. Nat Biotechnol. 2013 Aug;31(8):686-8.

105. Xie K, Yang Y. RNA-Guided Genome Editing in Plants Using a CRISPR-Cas System. Mol Plant. 2013 Nov;6(6):1975-83.

106. Belhaj K, Chaparro-Garcia A, Kamoun S, Nekrasov V. Plant genome editing made easy: targeted mutagenesis in model and crop plants using the CRISPR/Cas system. Plant Methods. 2013;9(1):39. 
